\title{
Poetry Customs and Traditions of Shahriyar: Shahriyar and "Sahandim"
}

\author{
Esmira Fuad (Shukurova)
}

\section{Institute of Literature named after Nizami Ganjavi, Azerbaijan National Academy of Science}

\section{Introduction}

Regardless of any poetry model, in which the poetic thought is expressed, the poet is always his own time and century's voice, its conscience, friend of his people, the protector of people who live frankly, not enticed of the world blessing and a heart, who speaks only the truth pertaining to his period, its wishes and intentions. One of the bearers of these passionate hearts is Doctor Seyid Mahammadhuseyn Behjat Tebrizi Shahriyar...

Who is Shahriyar? Shahriyar is the most powerful representative of Iran and Azerbaijani poetry of 20-th century, the classical poet and art genius estimated as Hafizi-sani and Sadi of his time. He was born in Tabriz city on March 21, 1905, in spring. Haji Miraga Khoshginabi Musavi, the poet's father was a well-known lawyer in Tabriz and his mother Kovkab khanim was a housewife. Haji Miraga, who has enjoyed universal esteem of his people, known as jack-of-all-trades, holding in high respect amongst the friends, at the same time being a protector of needy families and men was known as a personality taking care of truth.

Shahriyar lived in the Southern Azerbaijan, Iran, during some stages of the 20-th century which was characterized by severe class struggles and social-political fights for the national freedom, cultural progress. The period from 1905 to 1911 , when the Mashruta (Constitutional) revolution was taken place, the first stage of the democratic movement of the Southern Azerbaijani and Iran people against imperialist attempts and for the national independence coincides with the babyhood period of Shahriyar's life. To secure the life of his family, Haji Miraga decided to move from Tabriz, the center of vertical events to Khoshginab village of Abbas region. So, the life of Shahriyar passed in Khoshginab and nearest villages, such as: Gayishgurshag, Garachemen and Gipchag. 
Mahammad Huseyn, who got his initial education from Molla Ibrahim and molla Agha Mahammad Bagir, was taught writing and reading from his father, the wellknown intellectual of his time. In time, he improved his knowledge mastering "the Koran", "Divan" by Hafiz, "Gulustan" and "Bustan" by Sadi, as well as "Nassab" (A.N.Farhi), and the Arab-Persian dictionary written in verse.

Shahriyar, returning to Tabriz together with his family after stabilization of the state, extended his education initially in the religious schools of madrasa "Fuyuzat" and "Muttahida" and then in the secondary schools "Firdowsi" and "Mahammadiyya" and learned the Arabic, Persian and French languages on a perfect level. The works by Nizami, Hafiz, Sadi, Saib and Sabir (he wrote his first poem in Turkish language in 1913beinginfluenced by the great poet Mirza Alakbar Sabir) played an important role in forming of his reading skills and spiritual principles.

To continue his studies, Shahriyar arrived to Tehran in 1921 and registered for the university. In 1924, after graduation from the university, he was admitted to the medical faculty of Tehran University.

The young student charmed by the literature and the word art wrote very interesting poems and began to be recognized in the literary society in time.

His acquaintance with Tehran's well-known artists and science and culture figures has played an important role in shaping of his social views and his outlook. His acquaintance with "Igbali Azer" - Abulhasan khan Igbal us-Saltana, the outstanding mugham master of his time and his learning practice at this outstanding master's place to learn mugham influenced considerably on forming his outlook.

The young poet fell in love with Surayya, the sister of his classmate at university and continued to write poems with the pseudonym "Behjet" according to the name of the district Behjetabad where she resided and his first poetic examples raised interests amongst the well-known representatives of Iran poetry. His acquaintance with Abulgasim Shahyar in 1921 creates incentives for rapprochement with Lutfulla Zahidi (1922), Habib Salmasi, Ustad Gamarul-mulk Vaziri (1927), Malikush-shuara Bahar (1928). And he became friends with Arif Gazvini and Iraj Mirza with the help of M.Bahar.

As he wrote in his memoirs, when he started to write poems under one pseudonym, his pen friends imitated him, so he had to give up this pseudonym. Therefore, he was obliged to change his pseudonym frequently. Finally, he decided to tell fortunes with Hafiz's divan. In the opened page, there was written: 
The tricks of fortune have minted coins to the names of Shahriyars', And I must depart for my native city to be my own Shahriyar

(Shahriyar, 1993).

The poet, who has already determined his pen-name with the help of the divan wrote an ode "I am Shahriyar" in 1920, when he was 20 in this connection and called himself, in general, the poets the shah of the spiritual world. Iraj Mirza, after reading this ode approved his pen-name and declared with amazement: "You are not one of us; you are one in the line with the great Hafiz!"

But the great poet of future wrote his first poem when he was four, when his nanny was given him a cake with meat but not with rice.

\section{Rugiyya baji (My sister Rugiyya), Crown of my head, You must give meat to the dog And the cake to me}

("Mother Tongue", 1988).

Shahriyar after four years' education at Tehran University's medical faculty decided to be in a group of military physicians in 1928 and was qualified as military doctor.

But, as he was humanist, sensitive and fragile-hearted person and was fallen in love with poetry and art, he was not happy with doctoring and the surgeon's knife. Later, he remembered that his mood became worsened each time he was taken to observe the surgical operation (Ahmad Kaviyanpur).

Some poems of Shahriyar were published in Tehran mass media means during the university years (1924-1929). But his very first poem was published in the magazine "Adab" when he was student of Tabriz's Mahammadiyya School. Vahid Dastgirdi, the editor in chief of the magazine "Adab" feeling the brilliant future of the young Shahriyar and published his poems in his own magazine evaluating it highly.

In 1929, he tested his life's most success, so, his first poems' collection was published in Tehran's "Khayyam" publishing-house at the urgent request of his friends L.Zahidi, I.Mirza and M.Bahar ("Divancha"). He was encouraged to write and create art samples due to the fact of publication of his first collection of poems with the foreword of Malik-ush-shuara Bahar, Pejman Bakhtiyari and professor 
Said Nafisi, which was appreciated and evaluated highly by Tehran literary community.

In 1929, the 24 years old poet was obliged to come across with the greatest sorrow of his life, so, his beloved Surayya, who was called Pari in his poems was taken away forcedly of his hands and was wedded to Chiragali khan, the close relative of Rza shah and he was sent into exile to Nishapur. Despite he was intending to meet with Pari for the last time on the lakeside of Behjatabad and to take her off, he did not achieve his wish and the ways to happiness were closed to him atonce.

Shahriyar in the odes dedicated to this unlucky love, such as: "Memory of Behjatabad", "Pari", "Sorrowful wails", "Revenge for love", "Smell of the shirt", "Sad songs", "Moth burning at fire", "Moon in Safar", "Why now?", "Missing Yusif", "Anxiety" and "My destiny" described his ill-fated love and his feelings of longing. These odes have also contained a sharp protest and exposure against the time's ugliness, social evils and the disgrace perpetrated by the ruling circles. His troubled life during the period from 1930 to 1939, death of his father and the fact that he was far from his native lands when he passed away, loss of close relatives and friends and the failure of his first love and separation of his native lands during 8 years, in addition, the devouring accounting activity caused him to fall victim to the severe disease and psychological shock. The disease and moral crisis oppressing his spirit became deeper as time passed by. The poet tried within some period to be far from anything embracing him and to take him off any thoughts that caused him troubles. So, he decided to worship the God reverently and strives for mastering the philosophy of unity... As, Shahriyar wrote works obliging his readers to think regardless of his young years and confirmed himself as a poet of tasavvuf possessing the wisdom knowledge.

In 1952, his mother Kovkab khanim died in Tehran's Hezartakhttab hospital and was buried in the cemetery of the holy Gum city near to his father. He was shaken once again because of this event. He expressed his condolence in the gasida (ode) "O woe, my mother".

By the order of the Iran's Prime Minister issued in 1949, he was dismissed from the post of the head of the accounting service in the "agricultural and profession bank". And he failed to receive his salary for 4 months. And all these events put their negative impact on the poet's spirit and dragged him into the moral crisis.

In 1953, Shahriyar arrived in Tabriz and was employed by the agricultural bank. He loaned money and purchased a little home from Magsudiyya district near to Ark tower. The poet, being true to his first love within 28 years has finally decided to get married at the urgent request of his close friends and in august, 1953 he 
registered the marriage with Aziza khanim, the little daughter of his aunt Sayyara. His children born from this marriage: Shahrizad (1955), Abulhasan (1956, he died later), Maryam (1957) and Hadi (1959) brought joy to his languishing home.

The master poet died in Mehr hospital after long lasting serious illness - the pulmonary insufficiency on September 18, 1988. According to his testament he was buried in the cemetery "Magbarat-ush-shuara" (cemetery for poets) in Surkhab district of Tabriz.

The life and creative activity of Shahriyar may be divided into four periods: 1905 1930; 1930-1943; 1943-1975; 1975-1988.

The first period embraces Shahriyar's childhood and juvenile years. This period was significant by the publishing his first collection of poems ("Divancha").

The second period embracing 1930-1943 (luckless love) was the most difficult period of his life exposing to numerous and heavy grief and sorrow, reflecting his exile life and the deadly disease.

The third period of his life (1943-1975) passed relatively pleasurable for the poet and he was surrounded by successful events.

Despite the fourth period was coincided with the important social-political event as Iran Islamic revolution, it passed into the loneliness, deep grief and sorrow during his old years. During this period (1975-1988), the great art master wrote the works, such as, "Humanly Revolution", "God's promise", "Voice of time" seething with a joy as a result of rights and obligations imposed on the working people made a present for him. But later, in the works, such as, "what to do by melancholy poor", "Game with sorrow", "How the people get rid of", "My pie was filled in grief" "Predestination" Shahriyar underlines in a roundabout way that the rights and privileges were not presented and the revolution didn't create important changes and expressed his hardships arisen as a result of the destiny's heavy and relentless course.

But in the qasida (ode) written by him at his age 60 ("Division of my life") he characterizes his life dividing it into various and different periods. "What life can we speak about, just the half of these 60 years passed in dream and the half of the remained half was spent to the games during childhood years...? The remained half of the life period, called the youth was dedicated to meeting the material needs and in the remained last period we were exposed to the ugliness and old age... Who has found time to think, it is life and the remained period includes only beautiful dreams..." 
Even during this short time period enabling him to think about something, Shahriyar wrote his works, such as, "Greetings to Heydarbaba", "Stalingrad heroes", "Voice of right", "Mummified man", "Appeal to Einstein", "Ah My mother", "Legend of the night", "Poem and wisdom", "Language of the Turk", "Sahandiyya/My Sahand", "I have dome my grief sea" and other well-known works, which have evoked serious reverberation in each corner of the world populated by Turkic people and brought unparalleled reputation to their author. Some researchers consider "Sahandim" the masterpiece of Shahriyar's creative activity.

Why "Sahandim"? The great contribution of the great poet related to his people's life, its nature, language, cognitive resources and creative activity is that in these works, especially in the poem "Salute to Heydarbaba" he has described the life of Azerbaijan, its spirit and the beauties of this life realistically together its negative aspects, with the help of the perfect poetic language and he was able to convert the work into the expression of the people's internal world, the symbol of the national life. By this work he has caused Azerbaijan to be known by the Turkic world and other nations of the world.

"Salute to Heydarbaba" and other works shout for the world to recognize Azerbaijani grief, divided into two parts by the imperialist states, as Russia and Iran, writhed with the pain of separation within a period about two centuries, exposed to and squashed under the social inequality, its cry and scream. Shahriyar achieved the goals unattainable by the states and strong military leaders with the power of arms due to the miraculous authority of the word. He was able to unite the Turkic world spiritually. So, the poets from each country where Turkic people were populated after have been got excited have called out to Shahriyar. As a result, hundreds of poems were written to resemble Shahriyar's poems, lots of research works were done, new works and poems were created. In his turn, Shahriyar, approaching them with love and reverence has estimated highly these works.

But, among these works only two rhymes that fondled his heart; one, written by Bulud Garachorlu Sahand, the poet of Southern Azerbaijan. Sometimes, the poet became affective from cheers, encouragement and prayers, as well as a high evaluation given to his services addressed to his name and so he decided to write answers to the authors. The poem by the poet with the pseudonym "Sahand", originating from the mountain with the same name, the tallest mountain $(3900 \mathrm{~km})$ in the mountain range of the Southern Azerbaijan ("To the respected and great poet Shahriyar") traced deeply in his spirit. He has sensation of the unquenchable fire of love and the passionate poetic inspiration in the heart of Sahand, can hear the voice 
of rebellion...., as, in this poem Sahand shouted some truths, such as, the great Shahriyar was not lonely in this way of struggle, there were lots of supporters, for example, he was ready to walking shoulder to shoulder and it was necessary to go further and called his brother to write new works in the native Turkish language, finally to knock down the house of oppression with the power of the word.

\section{I hear their moaning, \\ The lion stayed pressed is crying. \\ Indeed, I am outrageous, \\ My Friend has been got into trouble and calls me.}

\section{Stand away and give way to pass, My heart has taken fire and I will emit flame. \\ Is Shariyar was fasten with a chain, I will chew and cast off these chains} (Shahriyar, 1993, p.469) ${ }^{1}$.

This deep sincerity, fiery desire, love and dismal kinship inspired Shahriyar, grew up his spirit and the successful result of this sincerity and the native attitude did not oblige the readers to wait more, the original art example and the art pearl ("Sahandiyya/Sahandim") was created. Then, Shahriyar begins to follow the creative works of Sahand with the merry inspiration and the perfect personality.

Shahriyar, acknowledging the Azerbaijani idea in the life as the base of the national character and national consciousness considered the main content of the poetry and poetic text is a man, social being and at whole the Azerbaijani people.

The key subject of the art and poetry of Shahriyar, who has accepted the Azerbaijani view to the life as a basis of the national character and the national consciousness is a human kind and at whole the Azerbaijani people. The main character and the content of the poem "Sahandim" (My Sahand) is a man, who is at the same time Sahand, the contemporary of the poet and Sahand Mountain, a part of the nature. Touching upon the reasons of creation of the work, the master poet has each time acknowledged that "I have dedicated this poem to Bulud Garachorlu Sahand, the Azerbaijani poet. The influence left by the poet Sahand was unforgettable. You know that I have devoted the poem "Do morg-e behisht" to Nima Yushich, the Persian innovator poet. But I know and understand that this poem is not able to reach the sommet of the poem "My Sahand". The poem "My Sahand" is such a work that completely contradicts dimensions of any poetic

\footnotetext{
${ }^{1}$ Mammadhuseyn Shahriyar, False world, the Azerbaijani Encyclopedia. NPB. 1993, p.469.
} 
model. I can dare to say that there was not created any poem with the same poetic energy than "My Sahand" all over the world."

Certainly, as Sahand was a free-thinking intellectual and progressive-minded personality, the great Shahriyar, remembering the death of this immortal poet in tears and said: "Heydarbaba, I kindly ask you to give birth to brave sons". It is to be noted that the poet Sahand was also one of the Azerbaijani brave sons" ("Varlig", 1988) ${ }^{2}$. The poet Bulud Garachorlufamed by Shahriyar is towered as the mountain of Sahand, he is a man of virtue, who fights against the despotic persons and servitude with his pen and finally he is a lover whose proud head is bent only before his people. When he writes poems, his imagination goes into a power dive, at this time he talks to angels, goes into rapture as nightingale and "when he whispers the words of any poem, as though he joins together the flower, pistachio and sugar and speaks eloquently and wisely". Shahriyar demonstrates the true humility before his literary hero, declares before his people and readers that "I, the invincible sultan of the art world, inclining my crown before Sahand. I discharged my flooded pearles treasure to the large hem of Sahand..." (Khushgenabi, 2013, p.46). The poet praises Sahand with such great love that the reader is obliged to be under influence of this immense love.

\section{See what respect there is in his furry hat \\ His crown is bent standing in front of Shahriyar \\ Pearls are his shoes now once were spread over him \\ His poem is an oracle, whispered by the angels \\ Being repeated in the honey-like lips... \\ ...There's a nightingale singing on a rose branch \\ In the arms of yellow wheat fields}

$$
\text { (Şəhriyar, 1993, p.46) }{ }^{4} \ldots
$$

Shahriyar understood that the face of the people and the nation, finally the national coloring was not only expressed in its appearance, his clothing, actions and behavior, they came into being by the life of the people, its environment, his mode of understanding the events and tendencies. He understood that "to describe truly any society, it is necessary to feel firstly its essence and characteristic features that may be reached only after understanding the rules being a basis for any society and

\footnotetext{
${ }^{2}$ The magazine "Varlig", September 1988, special issue. ${ }^{3}$ http://fikretsuleymanoglu.blogspot.com/2014/MohsunGardashKhushgenabi. http://www.butov.az; History of Southern Azerbaijani literature, Baku, "Ganun", 2013, p.46.

${ }^{4}$ Məhəmmədhüseyn Şəhriyar. Yalan dünya. Azərbaycan Ensiklopediyası. NPB, 1993, s.46.
} 
after estimation of these rules philosophically..."'(Şəhriyar, 1993, p.46). The poet understood that "his Sahand was a poet living freely. Sahand was characterized by his great personality" (Belinski, 1960, p.177), thus, the poet Bulud Garachorlu, glorified by the above-mentioned words of Shahriyar understood the rules of the society, feels its essence and was able to estimate them in the literary context and to draw attention of readers to these events... Namely thanks to these skills, the self-awareness process in the Southern Azerbaijan was accelerating and the national ideology and the Turkism were strengthened day by day...

The poem "My Sahand" is the most perfect example of modern poetry... Expressing the new and progressive subjects through new poetic models, in more flexible, simple, convenient and affordable forms, but not within the limits of the traditional poetic forms was a matter, causing anxiety for the poets during all stages of the history. With time, they have understood that the subjects bearing new social content do not find places in the old frames and the poetic models requiring equal length for all hemistiches, equal number of all syllables and observing the proportion between the long and short syllables.

In the first quarter of the twentieth century, M.A.Sabir, M.Mushfig, H.Javid, A.Javad and R.Rza, the poets of the Northern Azerbaijan have taken measures in simplification of the classic forms of prosody (arud) and in the way of creating the free arud forms. Whenever, only Rasul Rza, removing obstacles before the vers libre, destructing the restricted frame and ignoring any criticism and the ungrounded attacks of his colleagues wrote his poems in the new style - the verse liber rhythm.

The movement called "Tajaddud" (modernization and renovation) in Southern Azerbaijan commenced at the beginning of the last century, i.e. from 1915-1920, from the rise of the modernism movement in all countries of the western Europe approximately in $1920 \ldots$ The leading power of the movement Tajaddud, the renovation process in the poetry of the Southern Azerbaijani literature, concretely in the form and the content of the poem was included the names of Jafar Khamneyi, Shams Kasmayi and the young poet Tagi khan Rufat engaging in the active revolutionary activity, who was known one of the first creators of the modern Iranian poetry.

It is to be noted that Tagi khan Rufat was a founder of the newspaper "Tajaddud" embracing the fields of social and literary fields and the "School of Rufat" followed by the leading literary powers, such as Habib Sahir, Ahmad Khurram,

\footnotetext{
${ }^{5}$ Mammadhuseyn Shahriyar, False world, the Azerbaijani Encyclopedia. NPB. 1993, p.46

${ }^{6}$ Belinski V/G/ Works, Baku, Azerneshr, 1960, p.177.
} 
Yahya Arianpur and Mirza Danesh etc. He has even prepared and published the "Declaration of Modernists" determining the main goals and duties of the innovative poets, the impetus of the literary forces11 ("Varlig", 1988, p.119) ${ }^{7}$. Mirza Tagi khan Rufat, being a leading force for rising of Habib Sahir, his talented student, following his ideas and goals, his literary way with love and devotion to the level of "a father of the vers libre of the Southern Azerbaijan" (Huseyn Duzgun, Mahammad Rza Rasipur)" (Adam.az), the impetus of forming as a innovator and modernist poet has played outstanding role in forming and development of the Southern Azerbaijani poetry.

Shahriyar has appreciated the way followed by Mirza Tagi khan Rufat in his creative activity written both in the Persian and Turkish language and wrote his works from the standpoint of innovator. Shahriyar, providing the Persian poetry with new imagination and fantasy and the new mode of thinking with his poem "Legend" estimated highly Nima Yuzij, building "the bridge of changes" between the traditional poetry and the modernist ideas without repeating his predecessors and protected them against the bias attacks of various critiques, not approving the modernist poems. He acknowledged that the novelty of any poem is not only conditioned upon the form hereof, but also in its content and subject novelty and at the same time in skills to express these novelties and at whole in other mastery features and in his own works he created the unity of innovation and the traditional works.

He formed in Azerbaijan the new style and the new literary school referring to the traditions of Sadi-Rumi-Khayyam-Hafiz, at the same time the Azerbaijani folklore and those followed by Nizami, Gatran Tabrizi and Nasimi and recognized himself as the innovator poet ${ }^{9}$ (Rasipur, 2010, p. 268)... Sahriyar, considering the folk character and the literary creation in the living folk language as the main features of the innovation. Concretely, he did not rest upon the model of creating the romantic or realist work, on the contrary, the principal to follow innovatively the way in unity of the both movements. Certainly, despite the poet, keeping up the pace of the time wrote the most perfect works in the traditional style, in the classic poetry styles, in arud and syllable meter, he went through the style of vers libre meter and achieved to create successful modern works... Shahriyar, being sure that a poem, which is not able to express new idea and new significance will not be accepted, considered acceptable to write the poem in a language near to the live

\footnotetext{
${ }^{7}$ The magazine "Varlig", September 1988, Special issue, p.119.

${ }^{8}$ www.Adam.az.Internet site.

${ }^{9}$ Mahammad Rza Rasipur, "A look to the innovation of Habib Sahir", article, Peyk-e Azer, B., 2010, p. 268 .
} 
folk style and in a mode giving chance to ordinary people to understand it as one of the features of the poetic novelty...

In general, Shahriyar, as a master artist has considered true the provision of feasibility of writing the art works both in syllable and vers libre meters and has acknowledged this principle in the perfect works created by him. The fact of writing of many works, such as "Appeal to Einstein", "Mummified man", "Tehran and Tehran inhabitant", "Appeal of the Danube River to the humanity", "Appeal of Ulia HazratS hahbanu Farah in the congress of poets and writers", "mosaic, or artist", "Dreaming of the heart", "predestination", "Oh, my mother", "Khan nene" and finally "Sahandiyya//My Sahand" is the bright manifestation of the style pertaining to the Iran-Persian poetry in which the free poetic masters, such as, Nima Yusij, SayavushKasrai, Ahmad Shamlu, Rza Barahani, Nader Naderpur and Forug Forugzad have created poems and at the same time the free poetic traditions belonging to the epos "Book of My Dada Gorgud", the monument book to the Oghuz Turks. The highest point of this phenomenon is a poem "Sahandiyya/My Sahand"...

Shahriyar acknowledged that there was not created any work on the highest level as "Sahandiyya//My Sahand" has been written. This work may not be compared in any context and scale". (Kaviyanpur, p. 25). The poet, displaying his special love and profound respect towards Sahand, approving and acknowledging his pure moral and the perfect character has underlined in this poem the fact that the human power and self-confidence was considered the most important criterion for human kind in the personality of Sahand, as well as he has tried to persuade the reader the dynamic character of the relations between human kind and the God and it was the confirmation of the artistic perfection and wisdom displayed by the poet.

Within all creative life Shahriyar has observed and preserved the principle implying "a poem should be always rhymed" and "the essential point of any poem is concluded in its content and significance. The form is simply the clothing, poetic model and cover of a poem". As a rule, a writer is called a poet when his words are rhymed. As to the true writer, he wrote with the reasoning that he was a poet at the same time. He has recognized these ideas in the poem "Sahandiyya/My Sahand"...

The matter is that the content and the form of the work were completed by each other and the unlimited imaginations of the poet not fitting in the restricted poem model have spread their wings in the released freedom of the free meter.

\section{Shah mountain, my black hat, my support, my honorable Sahand, My foggy-headed Sahand...}

Tell the secrets as you get inspiration from skies, 
Wear your white fur, you'll wear green when it's spring,

You'll eat halwa of fires...

You have such sweet springs

on chest like swans'...

You have these coquets on the green flows

in a clear morning...

Let rain if it wills, let the flood go if it wills,

there are valleys aside

(bilinanadilin.blogspot.com) ${ }^{10} \ldots$

As it seen from this fragment, the poet has typified the Sahand mountain to which he has appealed as "My Sahand" as the triangle of human kind-woman-nature and treated it as a woman. The confrontation in the poem of the mother nature and a woman giving rise to human kind, the two productive beginnings with the marvelous literary language is extremely attractive.

To the mind of Guntay Genjalp, considering "My Sahand" as a masterpiece and the chef-d'oeuvre of all Shahriyar's works, "the poet considers the nature as a female

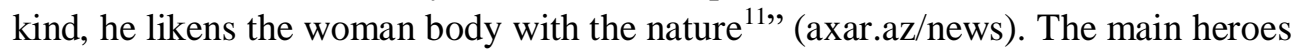
of "My Sahand" and its content is Sahand, the pen friend of the poet and the Sahand mountain, a part of nature. The deep philosophy exhibited by the poet in this work, the modern form and the content, high music, the rhythm playfulness and the mastery enables the reader to experience the world, to receive aesthetic pleasure from the art. The poem "My Sahand", estimated highly by the specialists as the bright example of the combination of the classic poetic traditions with the modern poem is loved namely thanks to its social content, national colorfulness, its flowing harmony, creating impression of rhythmic music in this degree. Certainly,the influence exerted on the poem of the original poetic form, considered rhythmic measure by some experts of the "Book of Dada Gorgud" is observed clearly, as, the versification met in "the Book of Dada Gorgud" is more archaic, more ancient and primary form of the Turkic-speaking poetry (Anar., 1985) ${ }^{12}$.

Surely, Shahriyar, regularly giving birth to some literary events, distinguished by his adherence to traditions by returning to the cultural heritage from time to time, taking the initial source of the Turkish poetry for himself created the real artistic miracle...

\footnotetext{
${ }^{10}$ http://bilinanadilin.blogspot.com/2010/09/shndiyy.html

${ }^{11}$ http://axar.az/news/45682

${ }^{12}$ Anar. "World of Dada Gorgud", magazine "Azerbaijan", 1985, No: 1.
} 
As he perfectly understood the true poem and writing poems, approached each novelty from the progressive position and did not turn back to the traditions. His position in the poetic disputes was neutral: so, he didn't imitate the European poetic forms as some "innovators" and didn't rattle the sable before the modern poetic form. On contrary, he followed the way of synthesizing the Oriental literary experience with the novelties of his time and with the successes of the western European literature and could set the correct balance between the traditions and the innovation. It was completely recognized by the successes reached by him in the poem "My Sahand". The poet considered the new poem an outstanding event of the time. The idea expressed by Mahammadrza Rasipur about the fact that "Shahriyar was footing at a time with this process of changes, therefore he was met by the society with feeling of kinship and fellow sufferer in all stages of his life" determines this direction of the poet's literary life correctly.

Folklore motives in "My Sahand". Sometimes Shahriyar, depending on his ideal and goal towards the images related to the legends or rumors approached the narrations under different angle and shed a light to some features and the significance contained in this legend. These series include the legends about Harut and Zohre, Yusif and Zuleykha, Suleyman and Bilgeys, Mahmud and Ayaz, Shaggulgamar, Noah's reed, Kalile and Dimne, Veys and Famin, AlifLeyli, Simurg and so on. In connection with these legends and rumors touched upon the images and events and most of time the reference to these events was well grounded. Let's go to the poem "My Sahand":

\section{Castle of zohre, its diamond fence is pearl and ruby Her castle is witchcraft, Harut and Marut are its engineers, Mani stayed here, stood before the images Door keeper is Harut}

(Azerbaijani Encyclopedia, p. 78) ${ }^{13}$

According to the legend, the star of Zohre (Venus) (the Venus means the beauty, music and the spell, goddess of witchcraft - E.Sh.) was a musician woman (tambourine player) having no equal in beauty. Two angels sent down by the God Harut and Marut fall in love with Zohre. They, stunned by her beauty teach her magic and witchcraft and they were engaging in philandering. Therefore, the both angels got punished by the God, they were deprived of their wings and were hanging upside down in the legendary Babylon well. As to Zohre, the goddess of beauty, music and spree she was punished because of the philander with the angels,

\footnotetext{
${ }^{13}$ Mahammad huseyn Shahriyar. False wold, Azerbaijani Encyclopedia NBP, p. 78
} 
as a result of which she was sacked from the Earth to the Sky. And she turned into the Venus, the Venus star and used in the classic poetry as a symbol of Harut, Marut, Babylon, spell, sorcery and the enchantment.

According to the other legend included in a commentary written by A.Jafar to the Nizami's works, supposedly this woman went the heaven because of the invocation learnt by her from the angels and turned here into the star Venus. The "Star of Venus" is considered in the Persian mythology the heaven musician. In Persian, it is called Nahid (Nizami, 1988, p.581) ${ }^{14} \ldots$

Certainly, using these legendary images, Shahriyar was not satisfied with only giving life to these characters and praising Shirvan, the land of poets located in the Northern part of Azerbaijan, the native lands of the great Sabir as a garden of paradise possessing mysterious beauty. Shirvan contained in the description of the poet is such a country of the world, here the houris (angels) carrying pure red wine glasses on their hands were lined up, the fish in the sea as a shining star, the nights by the silver light of the moon and the afternoons by the golden rays of the sun. The girls, the water beauties are swimming in the milk lake, poems and music are in full swing, the saz's become excited, the Venus star is flaunted in the balcony of the magic castle built from the diamonds, rubies, onyx, gold and other precious stones designed by Harut and Marut. The poet understanding this world with all his pathetic creates the legends of the Arabian Nights. The well-known artist Mani is wondered at this magical, mysterious beauty and his brush falls away. The highest and ardent patriotism of Shahriyar in this poem are purled. In this poem, he is appeared as a poet of the united Azerbaijan. In this poem, he transfers his ardent love for these native lands, as he resided and grown in Shirvan to the hemistiches and while praising his feelings he addresses regularly and in creative manner to the world of legend, tale, epos and folklore of our people. He gets power from the heroes of the legends "Book of Dada Gorgud", "Koroglu", "Rustam and Sohrab" and proudly refers to their names. Shahriyar was not satisfied with glorifying the beauties of the legendary lands of Shirvan:

Here, nights were covered with silver color

Wrapped in gold color

They were neither emerald mountyains nor marble plains

Neither yellow wire cows, nor pick-eyed bulls

And faces as moon

(Shahriyar, 1993, p.138) ${ }^{15}$.

\footnotetext{
${ }^{14}$ Nizami. Lyrics, Treasury of Mysteries, Sharafname, - Baku, Yazichi, 1988, p.581

${ }^{15}$ Mahammadhuseyn Shahriyar. Turkic Divan, B., Azerneshr. Elhuda-Sabah, 1993, p.138
} 
The poet resting upon the reader's imagination and memory selects the new remembering maneuver as his genius predecessor Nizami... The epithet "grey-eyed bulls and blond-haired cows" remembers another mythological motive. According to the myth, the Earth was standing on a bull (but the fact that the legendary land described by the poet was really standing on the legendary cows or bulls and it causes no doubt - E.Sh.). The poet, going down to the deep layers of the history wants to express the idea that we have not to forget the tale personages, such as, yellow cow, gold cow, black bull, grey bull and so on, which may be created from the deep faith of the ancient Turks to the bull as a totem. And the genius Nizami writes it directly, but not through remembering.

\section{Ground is on a stumbling and drowsiness bull, Whatever we construct it has broken and sent us to the grave}

Nizami possessing in-depth and comprehensive knowledge and a broad outlook considered that the instant stumbling of the said bull may cause terrible earthquakes on the planet and the formation of the vortex (Nizami, 1988, p.531) ${ }^{16}$. The facts proving benefiting from the folklore motive by Shahriyar are rich.

\section{I have received voice of Dada Gorgud and said:}

He is my supporter; $I$ believe in it

(Shahriyar, 1993, p.58) ${ }^{17}$.

As we know, the naming is one of the ancient ceremonies of the Azerbaijani people. This ceremony has been reflected more thoroughly in the legends "Book of Dada Gorgud", one of the pearls of our folklore. The majority of heroes in the epos legends were named only after showing courage in the corresponding situation, which was glorifyied by the gopuz of Dada Gorgud: Beyrek, Basat, Burgaj and so on. The hero of Shahriyar, i.e. BuludGarachorlu, the poet having invincible faith was named as Sahand, the mountain.

When the March wind strikes down the bowers,

Primrose and snowdrops appear from the frozen earth, When the clouds wing their white shirts,

Let us be remembered once again

Let our sorrows rise up like a mountain

(Shahriyar, 1993, p.58) ${ }^{18}$.

\footnotetext{
${ }^{16}$ Nizami. Lyrics, Treasury of Mysteries, Sharafname, - Baku, Yazichi, 1988, p.531

${ }^{17}$ Mahammadhuseyn Shahriyar. Turkic Divan, B., Azerneshr. Elhuda-Sabah, 1993, p.58
} 
Shahriyar resting upon the great Nizami said that Sahand, who has become the sultan of the art world after obtaining his crown from the hands of lion was towered to this sommet thanks the method learnt from the Phoenix. Let's look at the song of all these facts:

\section{And the rabbits scurry from flowering bush, When your garden burst into full bloom, May those who remember us live long? And may our saddened hearts be gladdened}

(Shahriyar, 1993, p.58) ${ }^{19}$.

\section{When we look at "Sahandiyya" through the paradigm of poetic qualities...} Shahriyar wrote "Sahandiyya" with great skills of mastery. The literary value of a classical poem, metaphors, sometimes exaggeration and softness of the used words are pointing at the beauty and flaw of the poem. The poem is so attracting that when the reader begins to read the poem he cannot easily put the book away.

Putting in a row of the radif words such as, "dagli", "dag", "tay", "ayag", "chirag", "bulag", "gulag", "galag", "uz", "goz" and "oldu" in the corresponding proportion in the above referred fragment, the joint phonetic velocity of the vocals "d", "l" and "q", in addition to securing the musicality and harmony of the poetry had brought pleasant beauty to the fragment. The consistent alliteration of the consonant and vowel sounds in the poem being the reflection of the artistic perfection shows itself as an interesting and unique harmony and an aesthetic and stylistic quality. The other aspect of the highest mastery in this sample is that Shahriyar had not used the metaphorical compound words, such as, "scarlet cheek" and "bud lips" in puzzled situation and in stillness, but, quite on the contrary, in moving condition: so, tears are becoming a lamp after dropping, the scarlet to the cheek after blossoming, and the bud to the lit after being laughed. The water of Aras river turned into bright dawn under influence of the sun's rays and at the moment of insisting of attempt of meeting of brothers longing for each other after a long separation upon the thorny wires and the border, the hearts are becoming ears, eyes - the spring, grief - pile and heads - feet ... It is to be noted that this type of originality beautifies the poem, provides it with high artistic value and displays the perfection of the poet as an artist...

\footnotetext{
${ }^{18}$ Mahammadhuseyn Shahriyar. Turkic Divan, B., Azerneshr. Elhuda-Sabah, 1993, p.58

${ }^{19}$ Ibid. p.57
} 
Heydar Baba, may your brows be bright.

May you be circled by streams and gardens?

And after us, may you live long.

This world is full of misfortunes and losses.

The world is replete with those bereaved of sons and orphaned.

Heydar Baba, my steps never crossed your pass.

My life was spent, becoming too late to visit you

I know not what became of all those beautiful girls.

I never knew about dead, about paths of "no return

I never knew about separation, loss and death

(Shahriyar, 1993, p. 80) ${ }^{20}$.

According to the ideas articulated by Shahriyar, regardless of expressing his poetic thoughts in what literary style, the poet is always the voice and conscience of his own time and century, the friend of his countrymen, the refuge for the oppressed people. The poet is a passionate heart declaring wishes and desires of this society and as a whole the individuals of this society. And the owner of this passionate heart had to tell the truth. As it seen from the above mentioned hemistiches, the poem "My Sahand" is a rostrum declaring loudly these facts - the sorrows of the people, living in the pain of separation during about two centuries.

It is to be noted that the poem "My Sahand" written in the free poetry style doesn't find place in any existent literary rule and measure and is completely new type of poetry. The rhyme system of this poem written as per the requirements of arud, partially syllabic measure and more the free verse meter doesn't comply with the classic form and sometimes, three, four, five, six, seven and more hemistiches after two or three rhymes and even eighteen lines are rhymed. In the below mentioned fragment, nine hemistiches are rhymed with the radif-models of one corresponding word and the remained four hemistiches with other word models:

a- night is an eye of right, created it in its hearth,

a - Harts are melted away in its lamp,

a - wine drunk a love and tulip is germinated on its cheek,

a - He is a guy that fairies drink water from its bowl,

a - Pearls are hot-spring,

a - His inspiration is beloved nightingale that sang in the rose branch

a- min the arms of yellow spike.

${ }^{20}$ Ibid. p. 80 


\section{a - Waters will tell legends in its magical garden, a - in the foggy time of morning. b-Poet's delight is so pleasant and what fantastic gardens, b - What gardens that tell legends as "AlifLayla". b-fire fell in the mountains. b- rose smiles but spring is crying (Shahriyar, 1993, p.55) ${ }^{21}$.}

It is necessary to stress once again that the hero and the content of the poem "My Sahand" include the human kind, i.e. the coeval of the poet Sahand and the mountain Sahand, i.e. the Mother Nature and the occurred natural events. As it seen from this fragment, while writing the poem, Shahriyar, whose inspiration was murmuring as a mountain river has broken the limits of the traditional poetry models, as a result of which there was created a quit new poetry kind where the meter. Rhyme and radif in this new model are free, the rhyming of the hemistiches is reflected through the system of a-a; b-b-b; v-v-v; d-q; d-q; d-q; d-q; c-c-c-c; e-e-

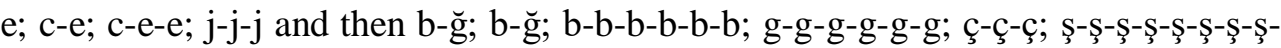
ş-ş and so on. So the rhyme order is lined up sometimes by the word units of 2-3-45-6-7-9-11-12 and even of 18 radif, but despite this unique lining up is lengthened, it was not became tiresome, the words selected with original mastery and fineness are intuitively connected one to another as the colorful carpet loops and are appeared before the reader as a mysterious beauty, as the measure, rhyme and radif's in the poem are the most beautiful samples of the unity of the classics with the modernity.

To secure the figurativeness of the poem "My Sahand", Shahriyar had used regularly the metaphors, which were understood easily and those enabling to create a junction amongst the words' figurative significances. Sometimes he uses the metaphors whose significance were unclear at the first glance in the structure of any word or phrase with such a skill that this special environment reveals at once the metaphoric significance. For example: in the hemistiches "“dağ-misdaq", "məşq-məş-şaq-eşq-müş̧aq", "söygülü-bülbüll-güll”, "əfsanə-əfsun”, "xəzanxəzəl”, "mavi-səmavi-müsavi-ravi”, “ağ-bağ”, “çıraq-qulaq-ayaq-bulaqqalaq-sayaq-damaq-da-raq-yataq-yanaq-dodaq", "karvan-heyvan-sarvanŞirvan”, “can-qan-sultan-qurban-oğlan-ceyran-qaflan-aslan", "fəvvarə-mehparə-güşva-re", "boğaz-qaz-qız"”and as whole in the poem's text, the particle "ne" used intensively serves the strengthening the metaphor and expressing the main idea more emotionally and more effective. Despite the words "fox and rabbit" were used separately in the capacity of metaphor they are understood easily thanks

\footnotetext{
${ }^{21}$ Mahammadhuseyn Shahriyar. Turkish Divan. B., Azerneshr, Alhude-Sabah, 1993, p.55.
} 
to the existence of the general context. The beautiful girls contained in his original description bear resemblance to the field geese swimming in the sea, gold or lake...

\section{Conclusion}

Shahriyar underlined the fact that the new modernist poem was created and developed from 20-30s of the 20-th century both in Azerbaijani and in the Persian literature and its roots were rested upon the Constitutional Movement Era and writing in this style was not a new event. The poet touched upon the fact that within the Middle Ages there existed the poetic forms, such as "mustezad" and "behri-tehvil" and considered important to write both in the traditional and in the verslibre meters. Shahriyar, the eternal protector of the language and the literature, accepting the novelties taken place in the art and applying these novelties in his own creative activity innovatively has recommended to be very attentive in this matter too. As per the opinions of the poet considering the first condition of writing beautiful poetry was concluded to be the true poet and versifying poems about the public troubles, "if the ghazal, gaside, gite and masnevi does not allow declaring the underlined topic, you have to appeal to the free poetry. The true poet is a person who is able to determine beforehand the possibilities of declaring the subject in the corresponding form. The perfect poet having all poetry models in his possession will not be opposite to any and special form, ${ }^{34,}$. As the poetry is an event of the time. And the time doesn't make any mistake at any time".

The poem "Sahandiyye//My Sahand was the appearance of the new poetry"...

\section{References and notes:}

Ahmed Vugar. Position and status of Shahriar in Persian poetry and literature // http://shahriyar.ru/

Anar (1985). "World of Dada Gorgud" // magazine "Azerbaijan", № 1(in Azerbaijani Turkish)

Belinski V.G. (1960). Works, Baku: Azerneshr. (in Azerbaijani Turkish)

Gardash Khushgenabi// http://fikretsuleymanoglu.blogspot.com/2014/Mohsun. History of

Southern Azerbaijani literature (2013). Baku, "Ganun" (in Azerbaijani Turkish)

Kaviyanpur Ahmad(1998).Life of Shahriyar, Monography, Manuscripts. Tehran.

"Mother Tongue" (1988) // Newspaper, Germany.

Mohammadi Masih Agha.Shahriar and his Era. Baku, 2015 (in Azerbaijani Turkish)

Nizami. Lyrics (1988). Treasury of Mysteries, Sharafname. Baku, Yazichi. (in Azerbaijani Turkish) 
Shahriyar Mammadhuseyn (1993). Turkic divan. Baku: Azerneshr. Alhuda-Sabah. (in Azerbaijani Turkish)

Shahriyar Mammadhuseyn(1993). False world, the Azerbaijani Encyclopedia. Baku: NPB. (in Azerbaijani Turkish)

Shahriyar Mammadhuseyn //http://www.butov.az;

Shahriyar Mammadhuseyn //http://bilinanadilin.blogspot.com/2010

Shahriyar Mammadhuseyn //http://axar.az/news/45682

Shukurova Esmira (Fuad)(2016). Mahammadhuseyn Shahriyar // "Azerbaijan" newspaper, December 5(in Azerbaijani Turkish)

"Varlig"(1988) // The magazine, September, special issue

\title{
Summary
}

\section{Poetry Customs and Traditions of Shahriyar: Shahriyar and Sahandim}

\author{
Esmira Fuad (Shukurova)
}

\section{Institute of Literature named after Nizami Ganjavi, Azerbaijan National Academy of Science}

\begin{abstract}
The poem which made Shahriyar popular among all Turkic people in the art world was "Hello to Heydar Baba". It was translated to 76 languages. This masterpiece of poetry written by the "Heydar Baba Poet" as he was called by various masters of word, has given him an unprecedented glory not only in Southern Azerbaijan and Iran, but also in the Middle East and in a number of countries around the world. The majority of literary critics consider the poem "Hello to Heydar Baba" as a poet's masterpiece. However, the poem "My Sahand", written in his mother tongue, is a special era in the poet's creativity, with a sense of mastery, poetic structure and meaning, as well as an improved work in terms of social content.
\end{abstract}

All natural events taken place in the poet's poetic description are related to the human kind and the living creatures are compared namely with the man. At the same time, the poet transfers the qualities of the human kind's spirit, such as sorrowing, laughing, crying, fighting and to be a prisoner, in short, all qualities that are inherent in human beings on the nature of the native lands with an artistic perfection, as a result of which he creates strong smiles, metaphorical periphrasis, as if carrying a pick on his hand is drawing colorful landscapes with charming beauty, inimitable tableau.

Key words: Iran and South Azerbaijan, Tabriz, Shahriyar, "Sahandim", modern poetry, nature, woman, poetics. 